\title{
Inhibition and Accelerated Autolysis of Trypsin due to Incorporation of Polymer of Oxidized Methyl Linolenate
}

\author{
Hideo Hatate*1 and Masamichi ToyomizU ${ }^{* 2}$ \\ (Accepted September 3, 1984)
}

\begin{abstract}
Bovine trypsin (EC 3.4.4.4) allowed to react with $\left[{ }^{1+} \mathrm{C}\right]$ polymer of oxidized methyl linolenate (oxd MLn) was analyzed by chromatography on Sephadex G-75, Sephadex G-25 and SP-Sephadex C-25. The incorporation of $\left[{ }^{14} \mathrm{C}\right]$ polymer was observed in high molecular weight fraction corresponding to trypsin molecule and low molecular weight fraction, decomposed products of tryp$\sin$. On the other hand, acetyltrypsin prepared by the modification of $\varepsilon$-amino groups in trypsin did not incorporate the polymer, so it was found that the incorporation was based on the carbonylamine condensation reaction. The polymer inhibited $\alpha$ - and $\beta$-trypsin definitely among trypsin derivatives and by reaction produced the inactive complexes. The complexes were easily decomposed by active trypsin and converted to low molecular weight fragments. So the authors concluded that the occurrence of the inhibitory effect of the polymer depended on the production of the inactive complexes but not on the acceleration of autolysis, which was the secondary phenomenon of the decomposed complexes.
\end{abstract}

It is well known that oxidized unsaturated lipids often caused toxicity to biological systems. In carp fed oxidized lipids, poor growth, high mortality and characteristic muscular dystrophy called "Sekoke" disease are observed. HATA and KANEDA $^{1)}$ studied the main toxic substance in oxidized lipid by using pure methyl linoleate hydroperoxide and secondary degraded products, and reported that the both revealed almost equal effect on carp as to muscular dystrophy, poor growth and inactivation of enzymes such as succinate dehydrogenase. Hata et al. ${ }^{2)}$ also suggested that most of lipid hydroperoxides were decomposed in carp intestinal tissue and converted to carbonyl compounds. But the real mechanism of toxicity is not clarified yet.

The toxic effect of lipid hydroperoxides and secondary degraded products has been widely studied by several workers. In contrast, that of the polymer of oxidized lipid is scarcely reported, because the polymer had not been supposed to be produced at a early stage of oxidation except for the polymer which occured at higher temperature. Recently, Mryashrta et al.,4) demonstrated the production of four types of dimer from oxidized methyl linoleate at the early stage, peroxide value 0.6. In addition, TAUBold et al. ${ }^{52}$ found out that the polymeric lipid was one of the main con- stituents in human brain lipofuscin. So the toxic effects such as described above might partly depend on the dimer or the more polymerized lipid.

The authors have been studied the inhibition of trypsin by oxidized lipid using methyl linolenate and found that the inhibitory effect of the polymer was definite among the fractions obtained from autoxidized methyl linolenate "(oxd MLn), ${ }^{6)}$ Furthermore, the inhibition was accompanied by the autolysis of trypsin, ${ }^{7)}$ but it is still obscure whether the autolysis will participate essentially in the occurrence of the inhibition or not. In this paper, the relation between the inhibition and the autolysis which were caused by the incorporation of the polymer was studied.

\section{Materials and Methods}

\section{Preparation of $\left[{ }^{14} \mathrm{C}\right]$ Polymer}

$\left[1-{ }^{14} \mathrm{C}\right]$ Linolenic acid (specific activity, 56.2 $\mathrm{mCi} / \mathrm{mmol}$; Amersham Ltd.) was converted to $\left[1-{ }^{14} \mathrm{C}\right]$ methyl linolenate (MLn) by the method of SCHLENK and GellermaN. ${ }^{8)}\left[1-^{14} \mathrm{C}\right]$ MLn (100 $\mu \mathrm{Ci}$ ) was mixed with $400 \mathrm{mg}$ of MLn (Tokyo Kasei Co.) and autoxidized at $40^{\circ} \mathrm{C}$ for 4 days in the dark. $\left[{ }^{14} \mathrm{C}\right]$ Polymer $(0.175 \mu \mathrm{Ci} / \mathrm{mg})$ was obtained from oxd MLn by chromatography on BioBeads S-X3 column as described previously. ${ }^{6}$ )

\footnotetext{
*1 Laboratory of Fisheries Technology, Faculty of Agriculture, Kyushu University, 46-04 Hakozaki, Higashi, Fukuoka 812, Japan（橎手英雄：九州大学裳学部水産学科).

*2 Ube Junior College, Bunkyo, Ube 755, Japan (豊水正道: 宇部短期大学).
} 


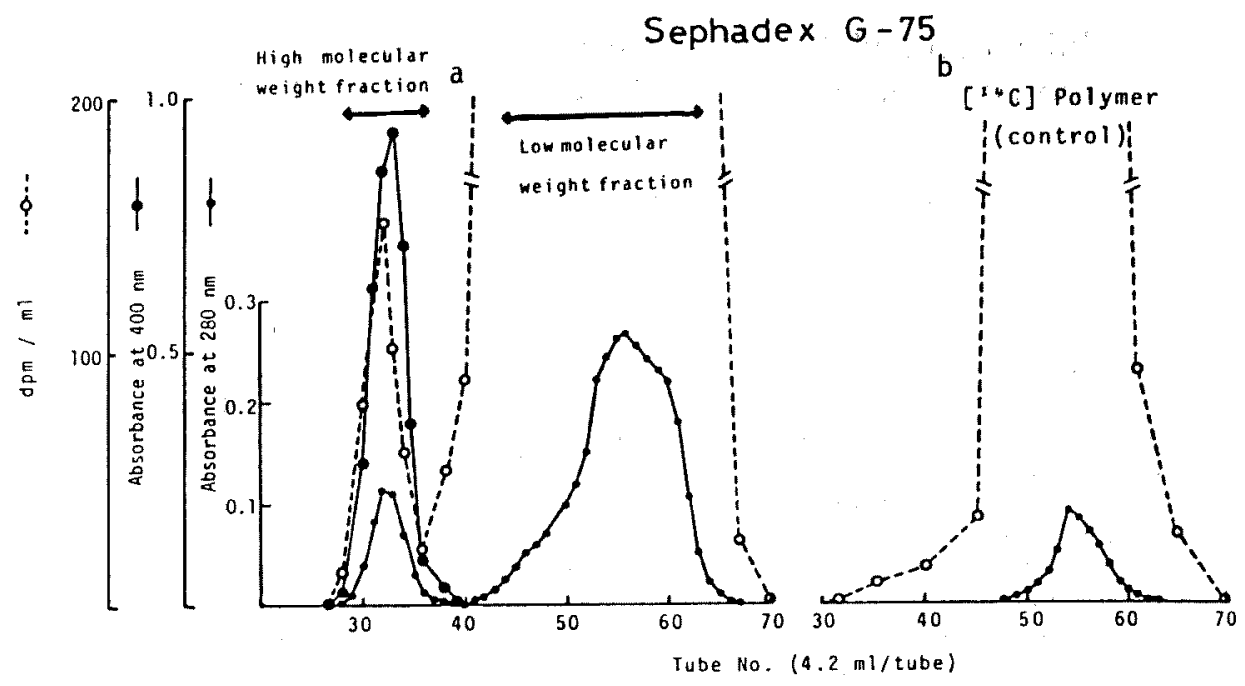

Fig. 1. Incorporation of $\left[{ }^{14} \mathrm{C}\right]$ polymer into trypsin.

Reaction of Trypsin with $\left[{ }^{14} \mathrm{C}\right]$ Polymer and Chromatography on Sephadex G-75

Bovine pancreatic trypsin ( $2 x$ crystallized) was purchased from Sigma Chemical Co. Trypsin $(10 \mathrm{mg}$ ) in $2 \mathrm{ml}$ of $0.1 \mathrm{M}$ Tris-HCl buffer ( $\mathrm{pH} \mathrm{9.0)}$ was allowed to react with $\left[{ }^{14} \mathrm{C}\right]$ polymer $(5 \mathrm{mg})$ in $50 \mu \mathrm{l}$ of EtOH at $37^{\circ} \mathrm{C}$ for $7 \mathrm{~min}$, unless otherwise indicated. After the reaction, the reaction system was mixed with $42 \mu l$ of $1 \mathrm{M} \mathrm{CaCl}_{2}$ at $0^{\circ} \mathrm{C}$ and then washed 5 times with ether. The mixture washed was chromatographed on Sephadex G-75 column $(142 \times 1.3 \mathrm{~cm})$ using $10^{-3} \mathrm{M} \mathrm{HCl}-0.1 \mathrm{M}$ $\mathrm{NaCl}$ as the eluent at $4^{\circ} \mathrm{C}$ and separated into high molecular weight fraction (HMWF) corresponding to trypsin molecule (M.W. 23,000) and low molecular weight fraction (LMWF). ${ }^{7)}$ Each fraction was tested on protein content (absorbance at $280 \mathrm{~nm}$ ), enzyme activity using $\alpha-N$-benzoyl-DLarginine-p-nitroanilide $\cdot \mathrm{HCl}$ (Sigma Chemical $\mathrm{Co}$; BAPNA) as the substrate (absorbance at 400 $\mathrm{nm})^{7,8)}$ and radio activity. Radio activity was counted in a liquid scintillation counter. Acetyltrypsin (Sigma Chemical Co.) or trypsin derivatives were allowed to react with $\left[{ }^{14} \mathrm{C}\right]$ polymer and treated as in the case of trypsin.

\section{Analysis of HMWF and $L M W F$}

Further analysis was carried out on HMWF and LMWF. HMWF was dialyzed against $10^{-3} \mathrm{M} \mathrm{HCl}$ and lyophilized. The sample was chromatographed on SP-Sephadex C-25 column
$(70 \times 0.9 \mathrm{~cm})$ using $0.1 \mathrm{M}$ Tris- $\mathrm{HCl}$ buffer $(\mathrm{pH}$ 7.1)-0.02 $\mathrm{M} \mathrm{CaCl}_{2}$ as the eluent.") LMWF was concentrated by lyophilization, dissolved in a small volume of $30 \%$ acetic acid, washed with $\mathrm{CHCl}_{3}: \mathrm{MeOH}(2: 1, \mathrm{v} / \mathrm{v})$ and then with ether. The sample was chromatographed on Sephadex G-25 column $(133 \times 1.4 \mathrm{~cm})$ using $10^{-8} \mathrm{M} \mathrm{HCl}$ $0.1 \mathrm{M} \mathrm{NaCl}$ as the eluent.

\section{Ultraviolet Differential Absorption Spectrum Meas- urment}

Ultraviolet differential absorption spectra were measured at room temperature in a Hitachi model 200-10 spectrophotometer.

\section{Decomposition of the Complex}

The complex produced by the reaction of $\alpha$ trypsin $(10 \mathrm{mg})$ with $\left[{ }^{14} \mathrm{C}\right]$ polymer $(5 \mathrm{mg})$ was eluted at the region corresponding to HMWF on Sephadex G-75 chromatogram. HMWF containing the complex was concentrated with polyethylenglycol (Wako Chemical Co., M.W. $20,000 \pm 5,000$ ), dialyzed against $10^{-3} \mathrm{M} \mathrm{HCl}$ and then centrifuged. The supernatant (Ca. 1,000 $\mathrm{dpm}$ ) was incubated with intact $\alpha$-trypsin (2.5 mg) in $4.5 \mathrm{ml}$ of $0.1 \mathrm{M}$ Tris- $\mathrm{HCl}$ buffer $(\mathrm{pH} 8.0)$ at $37^{\circ} \mathrm{C}$ and autolyzed. At suitable intervals, an aliquot $(0.3 \mathrm{~m} l)$ of the mixture was diluted with $2.75 \mathrm{ml}$ of $8 \%$ acetic acid. The diluted mixture $(50 \mu l)$ was used for the determination of enzyme activity toward BAPNA and the rest for the 


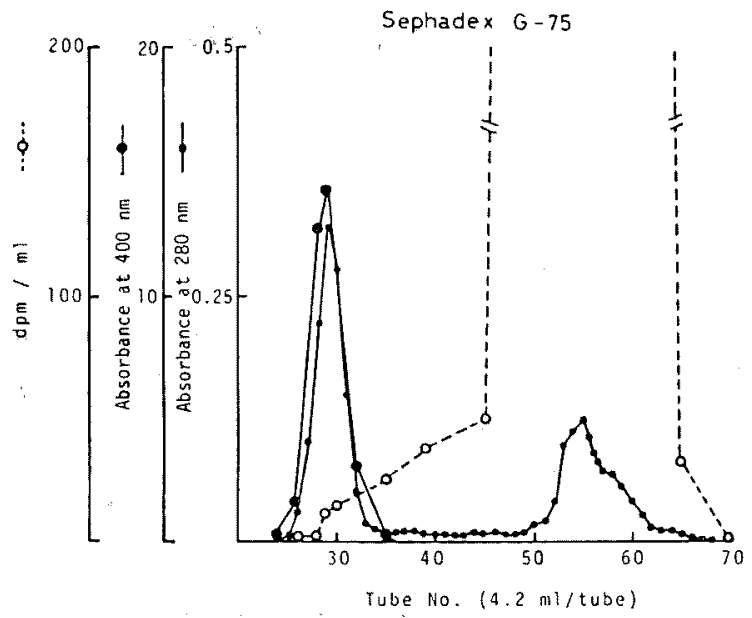

Fig. 2. Incorporation of $\left[{ }^{14} \mathrm{C}\right]$ polymer into acetyltrypsin.

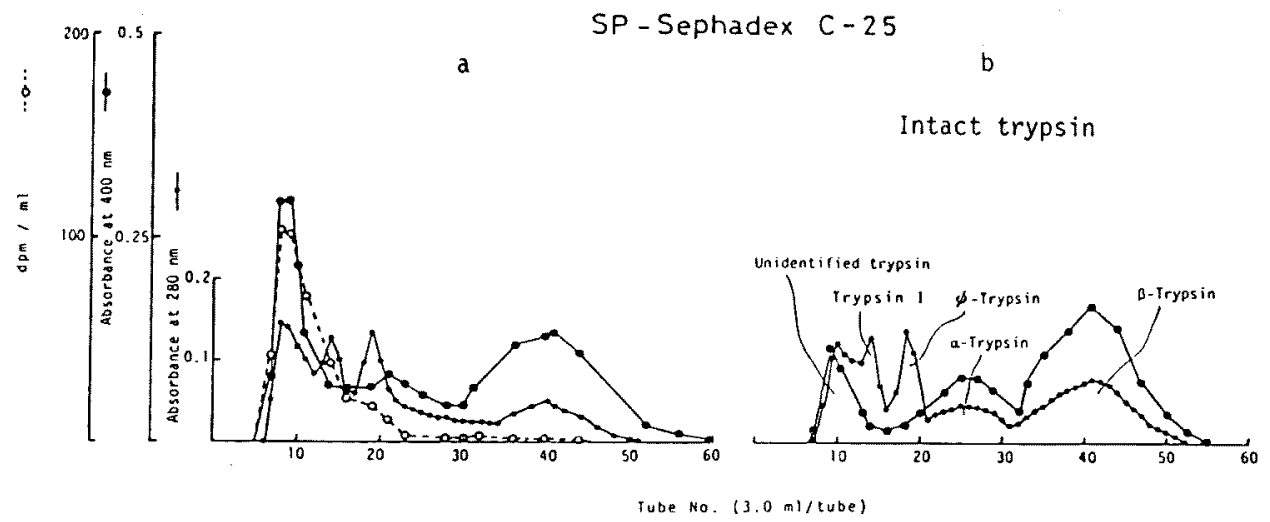

Fig. 3. Incorporation of $\left[{ }^{14} \mathrm{C}\right]$ polymer into high molecular weight fraction.

a) Trypsin $(30 \mathrm{mg})$ was allowed to react with $\left[{ }^{14} \mathrm{C}\right]$ polymer $(10 \mathrm{mg})$ at $37^{\circ} \mathrm{C}$ for $7 \mathrm{~min}$. High molecular weight fraction* was obtained by chromatography on Sephadex G-75. b) Intact trypsin (10 mg). * Refer to Fig. 1a.

assays of protein content and radio activity. The protein content and the radio activity were determined as follows. The rest $(3 \mathrm{~m} l)$ was suspended by mixing with $1 \mathrm{ml}$ of $24 \% \mathrm{CCl}_{3} \mathrm{COOH}$ and $25 \mu l$ of $2 \%$ sodium deoxycholate and then centrifuged. ${ }^{103}$ The precipitate was washed with deionized water and reprecipitated by the same procedure. The precipitate washed was dissolved in a small volume of $0.1 \mathrm{~N} \mathrm{NaOH}$. The solution was tested on protein content by the method of LowRY et al..$^{\text {in) }}$ and on radio activity in a liquid scintillation counter. Enzyme activity and protein content were used as an index of decomposition of intact $\alpha$-trypsin, and radio activity as that of the complex.

\section{Results}

\section{Incorporation of $\left[{ }^{14} \mathrm{C}\right]$ Polymer into Trypsin}

The separation of trypsin allowed to react with $\left[{ }^{14} \mathrm{C}\right]$ polymer was carried out by chromatography on Sephadex G-75 as shown in Fig. 1a. HMWF, which showed the enzyme activity, and LMWF were obtained as described previously. ${ }^{7)}$ Radio activity was detected in the both fractions, but the incorporation into LMWF appeared to be more 


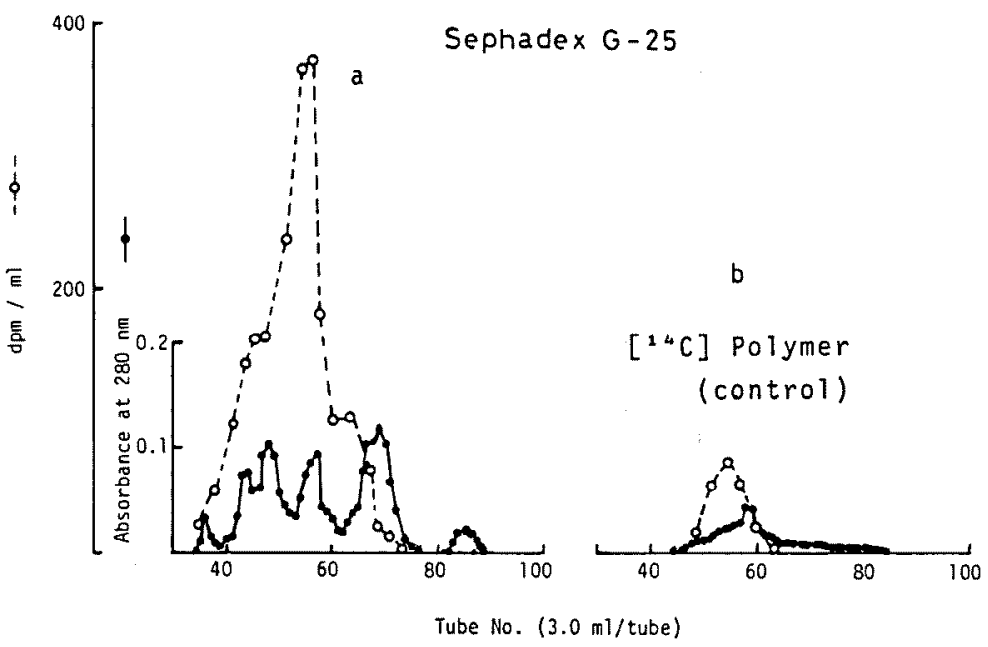

Fig. 4. Incorporation of $\left[{ }^{14} \mathrm{C}\right]$ polymer into low molecular weight fraction.

a) Trypsin $(30 \mathrm{mg})$ was allowed to react with $\left[{ }^{14} \mathrm{C}\right]$ polymer $(10 \mathrm{mg})$ at $37^{\circ} \mathrm{C}$ for $7 \mathrm{~min}$. Low molecular weight fraction* was obtained by chromatography on Sephadex G-75.

* Refer to Fig. 1a.

emarkable. At control experiment, $\left[{ }^{14} \mathrm{C}\right]$ polymer was eluted at the region corresponding to LMWF (Fig. 1b). LMWF in Fig. 1a might possibly contain the free $\left[{ }^{14} \mathrm{C}\right]$ polymer, which was not extracted with ether, as well as the associated $\left[{ }^{14} \mathrm{C}\right]$ polymer. On the other hand, acetyltrypsin prepared by the modification of $\varepsilon$-amino groups in trypsin ${ }^{12)}$ did not incorporate $\left[{ }^{14} \mathrm{C}\right]$ polymer and was scarcely inhibited by the polymer ${ }^{15}$ ) (Fig. 2). These indicate that the free $\left[{ }^{14} \mathrm{C}\right]$ polymer was not eluted at the region of HMWF and the incorporation of the polymer into trypsin was closely related to the inhibition of trypsin.

As shown in Fig. 3b, intact trypsin was separated into $\psi$ - $\alpha$-, $\beta$-trypsin and so on by chromatography on SP-Sephadex C-25. Two peaks of absorbance at $280 \mathrm{~nm}$ around tube Nos. 10 and 15 were designated as unidentified trypsin and trypsin I, respectively. ${ }^{7)}$ As to the incorporation of $\left[{ }^{14} \mathrm{C}\right]$ polymer into these trypsin derivatives, the reaction system used was slightly modified to leave a detectable amount of $\alpha$ - and $\beta$-trypsin (see footnote a) in Fig. 3), because a large portion of them was decomposed owing to the acceleration of autolysis of trypsin by the reaction of the polymer. ${ }^{7}$ After the reaction, HMWF obtained by chromatography on Sephadex G-75 was chromatographed on SP-Sephadex G-25 as shown in Fig. 3a. Radio activity was detected mainly at the region from tube Nos. 7 to 9 and was not in $\alpha$ - and $\beta$-trypsin remained. As describe later, the radio active fraction contained at least two components, the inactive complex (trypsin-polymer) and unidentified trypsin.

Fig. 4a shows the separation of LMWF, which was washed throughly to avoid the contamination of the free $\left[{ }^{14} \mathrm{C}\right]$ polymer prior to the chromatography. $\left[{ }^{14} \mathrm{C}\right]$ Polymer was incorporated remarkably into the decomposed fragments in contrast to HMWF in Fig. 3a. The difference of radio activity implies that the complexes would be decomposed easily by remaining trypsin and converted to low molecular weight fragments.

Inhibition of Trypsin Derivatives Due to the Production of Inactive Complex

As shown in Fig. 3b, the main active trypsin derivatives were $\alpha-, \beta$ - and unidentified trypsin. So the inhibition of them by various amounts of the polymer was studied as described previously, and shown in Fig. 5. The inhibition of $\alpha$ - and $\beta$-trypsin was evidently observed by increasing amounts of the polymer, although unidentified trypsin was scarcely inhibited. The inhibition of $\alpha$ - and $\beta$-trypsin was further studied from the incorporation of $\left[{ }^{14} \mathrm{C}\right]$ polymer.

HMWF obtained by the reaction of $\beta$-trypsin with $\left[{ }^{14} \mathrm{C}\right]$ polymer was separated into some derivatives due to the autolysis during the reaction period (Fig. 6). $\left[{ }^{14} \mathrm{C}\right]$ Polymer was incorporated into the 


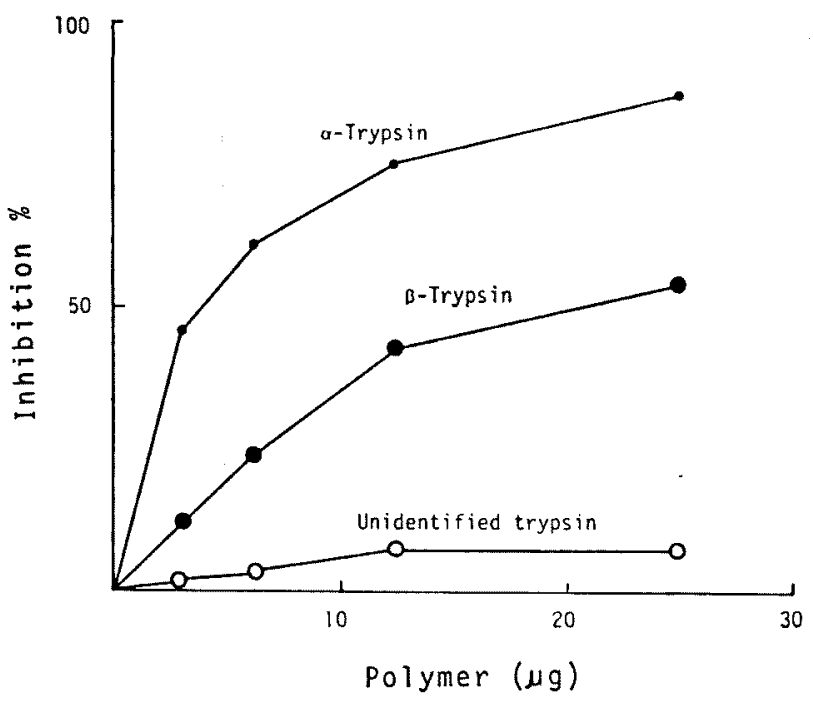

Fig. 5. Inhibition of trypsin derivatives by polymer. Trypsin derivatives were obtained from trypsin by chromatography on SP-Sephadex C-25. Each trypsin was pre-incubated with various amounts of polymer in $0.5 \mathrm{ml}$ of $4.8 \% \mathrm{EtOH}-0.1 \mathrm{M}$ Tris- $\mathrm{HCl}$ buffer $(\mathrm{pH} 8.0)$ at $37^{\circ} \mathrm{C}$ for $7 \mathrm{~min}$. Residual activity was determined using $1 \mathrm{~mm}$ BAPNA as substrate. ( $\alpha$-trypsin $20 \mu \mathrm{g}$, other trypsins $15 \mu \mathrm{g}$ ).

$$
\text { SP-Sephadex } \mathrm{C}-25
$$

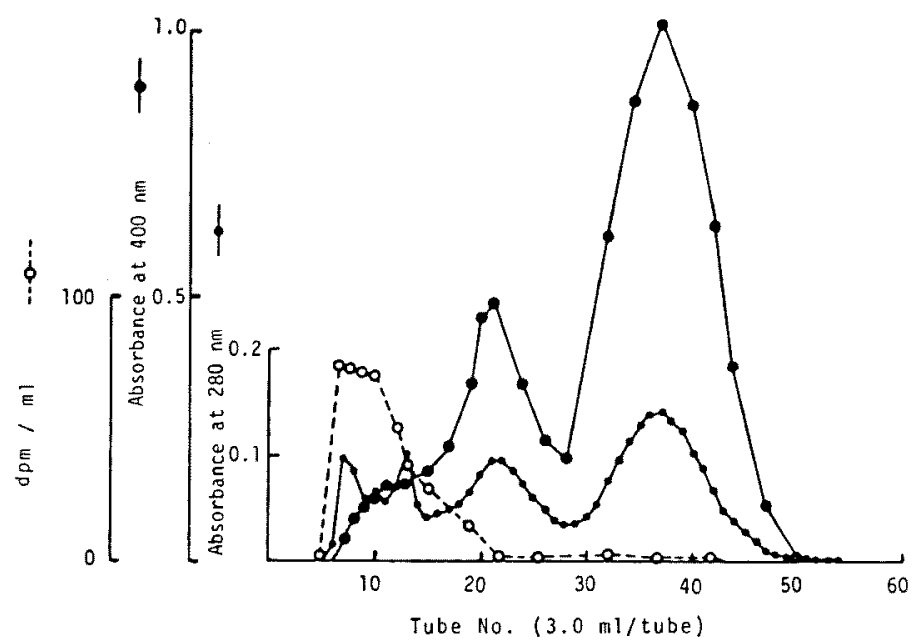

Fig. 6. Incorporation of $\left[{ }^{14} \mathrm{C}\right]$ polymer into high molecular weight fraction obtained after reaction between $\beta$-trypsin $(30 \mathrm{mg})$ and polymer $(10 \mathrm{mg})$.

small peak (absorbance at $280 \mathrm{~nm}$ ) around tube No. 7, which scarcely showed the enzyme activity. So the complex was different from unidentified trypsin: the complex might be eluted at the region by changing the affinity for SP-Sephadex from native $\beta$-trypsin. The ultraviolet differential absorption spectrum between the complex (tube No. 7 in Fig. 6) and intact $\beta$-trypsin is shown in Fig. 7. The negative peaks were observed at 285 and $292 \mathrm{~nm}$, suggesting that the complex would 


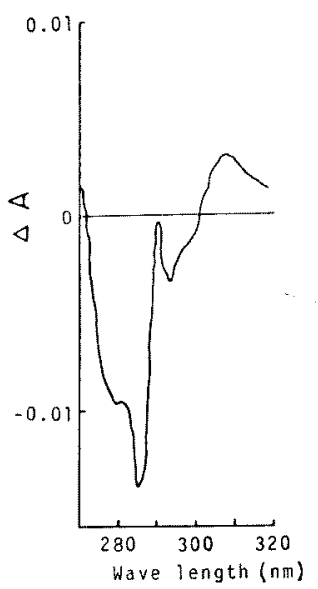

Fig. 7. Difference spectrum of $\beta$-trypsin before and after reaction with polymer.

Reference cell: $\beta$-trypsin $(120 \mu \mathrm{g} / \mathrm{m} l) ; 0.1 \mathrm{M}$ Tris- $\mathrm{HCl}$ buffer (pH 7.1) $-0.02 \mathrm{M} \mathrm{CaCl}_{2}$. Sample cell: tube No. 7 in Fig. 6.

change in its configuration and be apt to be decomposed. ${ }^{14)}$ In the case of $\alpha$-trypsin, the similar results were obtained (not shown).

\section{Decomposition of the Complex}

To clarify the phenomenon that the inhibition by the polymer was accompanied by the acceleration of autolysis of trypsin, ${ }^{7)}$ we studied the difference of decomposition rate of the inactive complex from native trypsin. The complex obtained by chromatography on Sephadex G-75 after the reaction of $\alpha$-trypsin with $\left[{ }^{14} \mathrm{C}\right]$ polymer was incubated with intact $\alpha$-trypsin and autolyzed. As shown in Fig. 8, radio activity decreased more rapidly with the prolongation of incubation time than enzyme activity and protein content. The result demonstrates that the complexes were decomposed more easily than native trypsin.

\section{Discussion}

Trypsin was strongly inhibited by the polymer containing carbonyl groups, but acetyltrypsin was scarcely inhibited. In addition, the fluorescent chromophores were produced by the reaction between trypsin and the polymer. ${ }^{13}$ So the authors supposed that the interaction depended on the binding between carbonyl groups of the polymer and $\varepsilon$-amino groups in trypsin. In this paper, the assumption was supported with regard

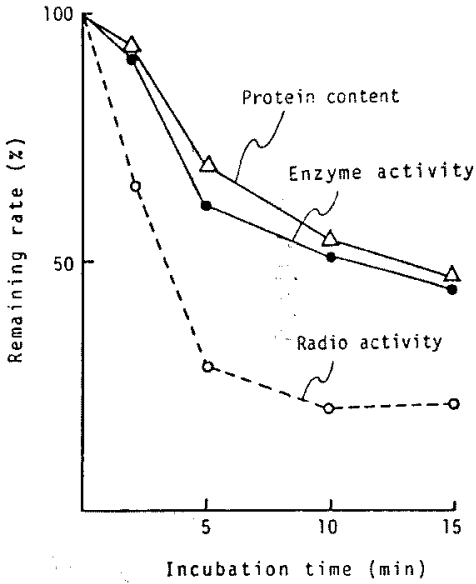

Fig. 8. Decomposition of complex produced by reaction between $\alpha$-trypsin and $\left[{ }^{14} \mathrm{C}\right]$ polymer.

Remaining rate of complex was estimated with radio activity and that of $\alpha$-trypsin was estimated with protein content and enzyme activity.

to the difference of incorporation pattern of trypsin from that of acetyltrypsin (Figs. 1a and 2). Nevertheless, trypsin can not be inactivated only by the modification of $\varepsilon$-amino groups in trypsin, for example, acetylation of $\varepsilon$-amino groups in trypsin with anhydrous acetic acid does not affect the enzyme activity, ${ }^{12)}$ so the modification is not a decisive factor for the inactivation of trypsin. In fact, the fluorescent chromophores were also produced by the reaction of trypsin with the dimer or the degraded products of oxd MLn, which scarcely inhibited trypsin. ${ }^{B, 13}$ On the other hand, the complexes produced by the reaction of $\alpha$ - or $\beta$-trypsin with $\left[{ }^{14} \mathrm{C}\right]$ polymer were inactive, and their configurations were changed (Figs. 6 and 7). This suggested that the inhibitory action of the polymer was mainly responsible for the configurational change introduced in trypsin molecule by the modification of $\varepsilon$-amino groups. To bring about the change, a particular molecular size such as the polymer (M.W. 90315) ) would be essential for the inhibitor. WILLIams ${ }^{16)}$ reported that the inhibition of enzymes was definite by the phenolic compounds, whose molecular weight were 500 or more. TAMIR and ALUMOT ${ }^{17)}$ also found that digestive enzymes such as trypsin, lipase and $\alpha$-amlyase were strongly inhibited not by tannic acid but by condensed tannins from carobs.

The incorporation of $\left[{ }^{14} \mathrm{C}\right]$ polymer into HMWF (Figs. 1a and 3a) was not so remarkable com- 
pared with that into LMWF (Fig. 4a), and the incorporation into the latter might involve the binding of $\left[{ }^{14} \mathrm{C}\right]$ polymer with decomposed fragments from trypsin. In addition, the complex from $\alpha$-trypsin was decomposed more easily than intact $\alpha$-trypsin (Fig. 8). These results will explain our speculation that the inactive complexes were decomposed, while produced.

The authors concluded that the occurrence of inhibition by the polymer was based on the production of inactive complexes, that is, on carbonylamine condensation reaction between carbonyl groups of the polymer and $\varepsilon$-amino groups in trypsin, which brought about the configurational change of trypsin. Moreover, the acceleration of autolysis by the polymer was the secondary phenomenon that the inactive complexes were decomposed.

\section{References}

1) K. Hata and T. Kaneda: Bull. Japan. Soc. Sci. Fish., 46, 997-1000 (1980).

2) K. Hata, M. Tanno, and T. Kaneda: Bull. Japan. Soc. Sci. Fish., 47, 51-56 (1981).

3) K. Mryashita, K. Fummoto, and T. Kaneda: Agric. Biol. Chem., 46, 751-755 (1982).

4) K. Miyashita, K. Fujimoto, and T. Kaneda:
Agric. Biol. Chem., 46, 2293-2297 (1982).

5) R. D. Taubold, A. N. Siakotos, and E. G. PERkins: Lipids, 10, 389-390 (1975).

6) H. Hatate and M. Toyomizu: Sci, Bull. Fac. Agr., Kyushu Univ., 39, 9-14 (1984).

7) H. Hatate and M. Toyomizu: Sci. Bull. Fac. Agr., Kyushu Univ., 39, 15-21 (1984).

8) H. Schlenk and J. L. Gellerman: Anal. Chem., 32, 1412-1414 (1960).

9) A. A. Dietz, L. K. Hodges, H. M. Rubinstein, and R. R. Briney: Clin. Chem., 13, 242-253 (1967).

10) A. Bensadoun and D. Weinstein: Anal. Biochem., 70, 241-250 (1976).

11) O. H. Lowry, N. J. Rosebrough, A. L. Farr, and R. J. RANDALL: J. Biol. Chem., 193, 265275 (1951).

12) J. Labouesse and M. Gervals: European $J$. Biochem., 2, 215-223 (1967).

13) H. Hatate and M. Toyomizu: Sci. Bull. Fac. Agr., Kyushu Univ., 39, 23-26 (1984).

14) C. H. Chervenka: Biochem. Biophys. Acta, 31, 85-95 (1959).

15) T. NaKamura and M. Toyomizu: Bull. Japan. Soc. Sci. Fish., 41, 59-64 (1975).

16) A. H. Williams: Proc. Pl. Phenolics Symp., 87-95 (1962).

17) M. TAMrR and E. Alumot: J. Sci. Food Agric., 20, 199-202 (1969). 